\title{
THE ROLE OF SUBJECT TEACHERS AS COUNSELORS IN THE TEACHING LEARNING PROCESS
}

\author{
Sutirna ${ }^{1}$
}

\begin{abstract}
Teachers have three roles in carrying out their duties, namely the role of educators, instructors and mentors. The role as an educator is always required to be a role model in his steps both in the school environment and in the community, then the role as a teacher always provides knowledge in accordance with his field in a humanistic manner, while the role as a supervisor is to deliver students to be able to overcome their own problems with encouragement and attention to his personality. Misperception about the task of implementing guidance and counseling services in schools is only done by guidance and counseling teachers, it seems that there needs to be an improvement in the perception of subject teachers. Therefore, to change this, universities as prospective subject teacher printers must provide guidance and counseling courses with explanatory content leading to the role of subject teachers as supervisors.
\end{abstract}

Keywords: The Role of Educators; Teacher Role; The Role of Guidance; Counseling Guidance for Subject Teachers

JOMSIGN: Journal of Multicultural Studies in Guidance and Counseling

Website: http://ejournal.upi.edu/index.php/JOMSIGN

Permalink: http://ejournal.upi.edu/index.php/JOMSIGN/article/view/6314

How to cite (APA): Sutirna. (2019). The Role of Subject Teachers as Counselors in the Teaching Learning Process. JOMSIGN: Journal of Multicultural Studies in Guidance and Counseling, 3(1), 51-63

This is an open-access article distributed under the terms of the Creative Commons Attribution 4.0 International License, which permits unrestricted use, distribution, and reproduction in any medium, provided the original work is properly cited.

\section{INTRODUCTION}

Quality, effective or ideal education is education that integrates three main areas of activity in synergy, namely the administrative and leadership fields, the instructional or curricular fields, and the fields of guidance and counseling. Education that only carries out administrative and instructional fields by ignoring the areas of guidance and counseling, will only produce counselees who are smart and skilled in academic aspects but lack the ability or maturity in aspects of personality (Kartadinata, 2008).

Then from the survey results on perceptions of Islamic Education Teachers of SMP/MTs in Karawang Regency, it was produced that the

\footnotetext{
${ }^{1}$ Universitas Singaperbangsa Karawang, Indonesia; sutirna@staff.unsika.ac.id
} 
knowledge of guidance and counseling had been a long time, but most PAI SMP / MTs teachers mistakenly interpreted that the task of guidance and counseling services was the duty of guidance and counseling teachers is not the task of the PAI teacher, so it is concluded that the teacher's role as a mentor is not implemented. (Sutirna, 2017)

In law number 14 of 2005 concerning Teachers and Lecturers in article 1 , it is explained about teachers and lecturers, "teachers and lecturers are professional educators with the main task of educating, teaching, guiding, directing, training, evaluating, and evaluating students in children's education. early childhood formal education, basic education and secondary education "(Culture, 2005)

Thus if we pay attention to Law No. 14/2005 above and the results of the survey, there is one role that has not been optimally performed by the teacher, namely the role as a supervisor. This is what is predicted as a cause and effect of the emergence of various phenomena of students in terms of brawls between students, personalities who are not students, acts of student crime and others in the form of deviant actions.

The wrong perception so far for subject teachers in schools about the task of guidance and counseling services is only the task of guidance and counseling teachers must need to change their perception into a positive one by providing a clear understanding since the lecture (as a student) in the subject of guidance and counseling especially for those who take educational programs while for subject teachers who have been assigned are given an education and training or the like regarding the teacher's role as a supervisor.

Furthermore, the reality in the field, based on the author's experience as a teacher and principal in one of the junior high schools in Karawang Regency, is that there are still many subject teachers who are given additional duties as guidance and counseling teachers. This is due to the fact that there is still a shortage of education personnel for guidance and counseling teachers, so for the ongoing process of providing education the principal provides additional tasks for subject teachers to become guidance and counseling teachers.

If we examine, first the quality and ideal education process if the three fields run synergistically by the teacher, namely the administrative and leadership fields, the instructional or curricular fields, and the guidance and counseling fields. Secondly, most of the survey results on subject teachers' perceptions of the implementation of guidance and counseling services are still 
wrong where the task of guidance and counseling services is counseling guidance teachers and thirdly the lack of inculcation of understanding, goals, principles, principles and foundation of guidance and counseling services when attending lectures. , then the purpose of education will not be optimal.

Based on the description above, the role of the subject teacher as a guide must be carried out, of course its implementation is different from the guidance counseling teacher. The implementation of counseling guidance services for integrated subject teachers during the teaching and learning process. This is in line with the results of research in a thesis entitled "Mathematics Learning Nuanced Guidance and Counseling" that mathematics subject teachers can substitute their guidance and counseling services during the course of teaching and learning activities. (Sutirna, Guidance Learning Mathematical Model at SLTP, 2004)

\section{LITERATURE REVIEW}

\section{Educator As A Guide}

Educating is not just merely transferring knowledge to students, but more than that. Basically educating is a process of helping to develop the personality of students. Problems, what is needed or needed by an educator in the guidance process (guidance and counseling)?

Understanding the guidance process is required to hold a personal reflection regarding the guidance experience that educators have experienced. Next Thio Riyanto conveyed the steps of the exercise to help education understand what guidance is, especially for subject teachers. (Riyanto, 2002).

\section{Exercise I:}

Fill in the questionnaire table below by reflecting on your own experience.

\begin{tabular}{|c|c|c|}
\hline No & Question & Your answer \\
\hline 1 & What does it mean to be a mentor? & \\
\hline 2 & What is your own description as a guide? & \\
\hline 3 & At what event did you become a guide for others? & \\
\hline 4 & What do you say? & \\
\hline 5 & What are you doing? & \\
\hline$\underline{6}$ & How do you feel about guidance? & \\
\hline 7 & What is the response of the person you are mentoring? & \\
\hline 8 & What really helped the guidance process? & \\
\hline$\underline{9}$ & What do you think is a good guide? & \\
\hline 10 & What attitudes and actions really help the guidance process? & \\
\hline
\end{tabular}


From the answers written through your experience will certainly greatly affect yourself and those who have been given guidance by you. The next exercise, please follow below as in the first exercise.

\section{Exercise 2:}

Refill each question presented below,

\begin{tabular}{llc}
\hline No & \multicolumn{1}{c}{ Question } & $\begin{array}{c}\text { Your } \\
\text { Answer }\end{array}$ \\
\hline 1 & What personal qualities have you been guided by? & \\
\hline 2 & What actions are taken after obtaining guidance from you? \\
\hline 3 & $\begin{array}{l}\text { What do you think are the attitudes and actions that can be taken to guide } \\
\text { students/someone who can help the guidance process? }\end{array}$ & \\
\hline
\end{tabular}

From this second answer exercise, it is seen and detected what actions should be taken by a supervisor in providing guidance services to students so as to produce the expected students.

From the description above, what needs to be considered for an educator before performing his role as a supervisor, Riyanto (2002) presents the following questions:

1. Why do I want to be an educator who is also a mentor?

2. Who do I want to guide?

3. What are the benefits if I guide others?

4. How can I make sure I can be accepted by other people I am mentoring?

5. What feelings emerge when I guide someone?

\section{Thought Need for Guidance}

The rationale for the implementation of guidance and counseling in formal education (schooling), especially for subject teachers, is not solely located on the presence or absence of a legal basis (legislation) or provisions from above, but more importantly is related to efforts to facilitate students who are hereinafter referred to as counselee, in order to be able to develop their potential or achieve developmental tasks (concerning physical, emotional, intellectual, social, and moral-spiritual aspects), because so far the BK teacher, in general, is still insufficient compared to the number of students in one school.

Counselee as an individual who is in the process of developing or becoming (on becoming), which is developing toward maturity or independence. To achieve this maturity, counselees need guidance because 
they still lack understanding or insight about themselves and their environment, as well as experience in determining the direction of their lives. Besides that, there is a certainty that the development process of the counselee does not always take place smoothly or free from problems. In other words, the development process always runs in a linear, straight line, or in the direction of the potential, expectations and values adopted.

The development of counselee is inseparable from environmental influences, both physical, psychological and social. The inherent nature of the environment is change. Changes that occur in the environment can affect the lifestyle (life skills) of citizens. If the changes that occur are difficult to predict, or beyond the reach of ability, it will give birth to the developmental gap in counselee behaviour, such as the stagnation (stagnation) development, personal problems or deviations of behaviour. Changes in the environment that are thought to affect lifestyles, and developmental gaps, including rapid population growth, growth of cities, disparities in socioeconomic levels of society, information technology revolution, shifts in the function or structure of the family, and changes in the structure of society from agrarian to industrial.

Unhealthy environmental situations and conditions, such as: the rise of pornography on television and VCD; misuse of contraceptives, intoxicants, and drugs / drugs that are out of control, disharmony in family life; and adult moral decadence greatly influences the behavior patterns or lifestyle of counselees (especially in their teens) who tend to deviate from moral rules (noble morals), such as: violations of discipline, brawl, drinking, drinking, becoming a drug addict or NAPZA (Narcotics, Psychotherapists and other addictive substances, such as cannabis, narcotics, ecstasy, putau, and shabushabu), crime, and free sex. Let us consider the following caricature drawings that we must correct the system of organizing education in Indonesia, where the emotional atmosphere and self-esteem are not guided by educators so far. Especially in September 2012, said to be a month of the brawl between students which resulted in death and even added brawls between citizens who are terrible.

Appearance of adolescent behaviour as above is not expected, because it is not in accordance with the personal figure of the aspired Indonesian human being, as stated in the national education goals (Law No. 20 of 2003), namely (1) having faith and devotion to God Almighty, (2) having noble character, (3) 
having knowledge and skills, (4) having physical and spiritual health, (5) having a steady and independent personality, (6) having a sense of community and national responsibility. These objectives have imperative implications (which require) for all levels of the education unit to always stabilize the educational process in a quality manner towards the achievement of these educational goals.

Efforts to deter and prevent unexpected behaviours as mentioned, are to develop the counselee's potential and facilitate them systematically and programmed to achieve the competency standard of independence. This effort is an area of guidance and counseling that must be carried out proactively and based on data on the development of the counselee along with various factors that influence it.

Thus, quality, effective or ideal education is one that integrates three main fields of activity in synergy, namely the administrative and leadership fields, the instructional or curricular fields, and the guidance and counseling fields. Education that only carries out administrative and instructional fields by ignoring the areas of guidance and counseling, will only produce counselees who are smart and skilled in academic aspects but lack the ability or maturity in aspects of personality (Kartadinata, 2008).

At this time there has been a change in the paradigm of guidance and counseling approaches, namely from traditional, remedial, clinical, and counselor-oriented approaches, to developmental and preventive-oriented approaches. Approach to development guidance and counseling (Development Guidance and Counseling), or comprehensive guidance and counseling (Comprehensive Guidance and Counseling). Comprehensive guidance and counseling services are based on efforts to achieve developmental tasks, developing potential, and alleviating counselee issues. Development tasks are formulated as competency standards that must be achieved by the counselee, so this approach is also called standard-based guidance and counseling.

In practice, this approach emphasizes collaboration between counselors and other education providers (Principals, School Committees, Teachers and administrative staff), counselee parents, and other relevant parties (such as government / private agencies and experts: psychology and doctor). This approach is integrated with the educational process in the equality education as a whole in an effort to help counselees to develop or realize their full potential, both in terms of personal, social, learning, and career aspects. 
On that basis, the implementation of guidance and counseling in formal education is oriented towards facilitating the development of counselee, which includes personal, social, learning, and career aspects; or related to the personal development of the counselee as a being with a dimension of biopsychososiospiritual (biological, psychological, social, and spiritual).

In the implementation of guidance and counseling services for subject teachers carried out during the teaching and learning process takes place or in other words, learning based on guidance and counseling.

\section{Guidance and Counseling Based Learning}

Guidance and Counseling is one of the integrated elements in the whole education program in the school environment. Thus the guidance and counseling are one of the tasks that should be carried out by every education personnel who work in the school. Although the role is clear, there are some education staff (subject teachers) who have not yet realized that guidance and counseling is part of their duties.

The guidance role of the subject teacher in the teaching and learning process is an integrated teacher competency in his overall personal competence. In this case, the role of the guidance is interactional adjustment competence, which is the teacher's ability to adjust to the characteristics of students and the learning atmosphere of students. This is reinforced by the Guidelines for Implementing the Pattern of Education Reform for Education Personnel (P4SPTK) in Indonesia, which is called the Teacher Basic Skills Profile where there are points about recognizing the functions and programs of guidance and counseling services and the point of creating a harmonious learning climate. (Beasiswa, 2012)

The guidance role of a subject teacher as an interactional adjustment in the meaningful teaching and learning process can be interpreted as the teacher's treatment of students by paying attention to the following:

1. Treatment of students as individuals who have the potential to develop and progress and are able to direct themselves to be independent.

2. A positive and reasonable attitude towards students. In the implementation of guidance, teachers do not distance themselves from students.

3. The treatment of students in a warm, friendly, humble, and pleasant.

4. Empirical student understanding. 
5. Respect for the dignity of students as individuals.

6. Self-appearance sincerely (genuine) in front of students.

7. Concreteness in expressing oneself.

8. Acceptance of students as is.

9. Treatment of students openly.

10. Sensitivity to feelings expressed by students and helping students to realize those feelings.

11. Awareness that the aim of teaching is not limited to students' mastery of teaching materials, but rather involves the whole development of students into more mature individuals.

12. Adjustment to special circumstances

The treatment of subject teachers in the teaching and learning process above is based on guidance and counseling, student learning success will be lacking, if only if the treatment described above one of them disappears from the behaviour of subject teachers when providing learning.

Thus the role of guidance in the learning process largely determines student learning success in the form of personal results. The classroom atmosphere which is motivated by human interaction encourages teachers to not only transfer knowledge but also encourage students to learn more optimally. In other words, the classroom atmosphere that is coloured by human interaction will encourage students to be more involved in the learning process intellectually and emotionally. Students perform assimilation and cognitive accommodation to gain knowledge, act and experience directly in developing skills and comprehension and internalization in the formation of attitudes and values. Such a process will multiply the meaningfulness of learning for students, so learning is no longer coercion or burden but is a necessity.

\section{The Role of Teachers as Guides}

The role of the teacher means the overall behaviour that must be done by the teacher in carrying out his duties as a teacher. Teachers have a broad role both in school, in the family, and in the community. The teacher is a major factor in the whole education process. In their duties as educators, many teachers apprentice various types of roles that inevitably have to be implemented as a teacher. Teachers have a key role and position in the whole process of 
education - especially in formal education - even in community development in general (Natawijaya, 1984).

Furthermore, a good and effective teacher is a teacher who can play these roles well. These roles are as a learning designer, teaching manager, assessor of learning outcomes, instructing instructor, and as a student's guide. (Surya, 2004). Then Moddy in (Natawijaya, 1984)) gave a very supportive article on the role of teachers both in schools and in the community, namely:

"....the success of organized society depends largely upon the teacher. She must be conscious that she is performing the highest type of service to society and that her profession must be on as high a level as that of any other. A teacher's personality plays a most important part in her teaching success."

From these sentences, it turns out the teacher's sincerity is the most important part in achieving learning success so that students will have quality. Rochman Natawidjaja (1988: 31-32) states that in relation to the teacher's role as a supervisor there are three main tasks of the teacher, namely:

a. Professional Duties, i.e. tasks related to their profession, this task includes the task of educating (developing students' personal), teaching (to develop students' intellectuals), training (to develop students' skills) and managing order as supporting school resilience.

b. The task of humanity (human responsibility), namely the task as a human being, in this case, the teacher's duty is to realize himself to be placed in humanitarian activities and in accordance with human dignity.

c. Community service (civic mission), namely the task as members of the community and citizens. In this case, the teacher is tasked with guiding students to become good citizens in accordance with the rules contained in Pancasila and the 1945 Constitution and the GBHN.

In the teaching and learning process, these three tasks cannot be separated one by one but instead become an interconnected system. Thus once again, the teacher not only conveys material, applies suitable methods, evaluates student work and other assignments that are not reflected as above, but the teacher is his personality, that is his overall appearance and manifestation with students.

Bernard in (Natawijaya, 1984) states that the personal teacher is more than what is said and the methods used, as a determinant of the level and direction of student growth. So it is precisely what Moddy stated that the 
success of an organized society depends very much on the teacher. Houtson in (Natawijaya, 1984) argues that the subject teacher acts as an effective guide is a teacher characterized by:

a. Subject teaching, the teacher who:

1) Is able to arouse interest and enthusiasms in the subject taught.

2) Has ability as a leader of pupils and as an orientation teacher.

3) Is able to relate the subject to practical fields of work.

b. Pupil-teacher relationship, the teacher:

1) Whom pupils seek for advice and help.

2) Who seek contacts with young people, outside classroom.

3) Who lead clubs an activities.

4) Who has made home contacts.

c. Teacher relationship, the teacher who:

1) Has shown ability to win cooperation of other teachers

2) Does not arouse antagonism

3) Has shown ability to stand critic

4) Has shown unselfish leadership

5) Record and Research, the teacher who:

d. Has a scientific objective attitude

e. Prefers to measure not guess

f. Has interest in research problems

$g$. Is efficient in research in clerical routine

h. Sees an apprtunity for research in clerical routine.

Thus the teacher's role as a mentor is very broad, not only in teaching as a teacher of certain subjects. On the other hand also how attitude and professionalism in teaching will become a very decisive role for its development towards a better direction. Therefore, the teacher is a facilitator in learning not the other way to be difficult for student learning.

Furthermore Gibson et. al in (Natawijaya, 1984)) said that teachers are the key and highly professional experts in overall school activities. The teacher provides important support and participation in a program given to students.

The teacher in the teaching and learning process he not only uses an instructional approach but also through a personal approach (personal approach) so he is required to understand students in-depth so that he can help in the whole learning process. As the 'director of learning,' the teacher also 
acts as a guide in the student learning process. What the teacher must do is as follows:

1) know and understand each student individually and in groups;

2) provide the information needed in the learning process;

3) provide adequate opportunities so that each student can learn according to his personal characteristics;

4) assisting each student in overcoming the personal problems they face;

5) assess the success of each step of the activity that has been carried out. (Kusmiharto, 2007)

From the description it is clear the importance of subject teachers understand about guidance and counseling services (it does not mean seizing the duties of the Guidance and Counseling teacher, but rather its role in the learning process of the effective subjects) so that it can run systematically and/or cooperate with the Guidance and Counseling teacher in providing guidance and counseling services.

\section{DISCUSSION}

Of the events carried out by students (students) where their personality tends to go bad, inevitably it is one indicator of failure in the process of providing education, wherein there is no optimal prevention function through guidance and counseling services of all components of educational organizers.

Especially with the development of the world of information and technology that is increasingly sophisticated, that can not be guessed by the ability of human reason so that what is feared is the negative impact of the development of IT. Thus guidance and counseling services for students must be carried out by all schools and colleges as a step to anticipate and strengthen the personality of students for today and in the future.

Subject teachers in schools in general compared to the Guidance and Counseling teacher seems to be the subject teacher who often meets with students, at least once a week to meet in class compared with the Guidance and Counseling teacher, therefore the teacher's role as a supervisor has to be done for the eye teacher lessons to guide in the meeting during the teaching and learning process. With a note not to overtake the task of the Guidance and Counseling teacher, reach the Guidance and Counseling teacher as a friend or colleague to jointly overcome the problems of students if the subject teacher with no service moves. 
By paying attention to the wrong perceptions so far for subject teachers on the task of guidance and counseling services in schools, universities that organize educational study programs should inform and provide explanations in guidance and counseling courses so that if a student plunges directly into a subject teacher already know their role as one of them as a guide. Therefore, for guidance and counseling lecturers who are tasked with giving Guidance and Counseling courses in non- Guidance and Counseling study programs, it is expected to be able to explain the differences between Guidance and Counseling teachers and Subject Teachers when performing their roles as supervisors.

\section{CONCLUSIONS}

From the preliminary description, literature review and discussion, the writer will present several conclusions, namely:

1. Quality education if the three roles of the teacher are carried out synergistically, namely acting as educators, instructors and mentors in carrying out their daily tasks.

2. Subject teachers should change the paradigm or wrong perception of the implementation of guidance and counseling services about the task of guidance and counseling services is the task of guidance and counseling teachers.

3. The implementation of counseling services for subject teachers is carried out in an integrated manner in the teaching and learning process, which subsequently the authors say "Learning in Guidance and Counseling Subjects".

4. Guidance and counseling must be carried out by all school components (Supervisors / Inspectors, Principals, School Committees, Subject Teachers, Guidance and Counseling Teachers, Administrative Staff, and Caraka) using methods that are in accordance with their main tasks and functions.

5. The tertiary institution organizing teacher printing should be explained in the guidance and counseling subject about the importance of counseling for subject teachers in a contextual, theoretical, and realistic manner about the subject teacher having a role as a supervisor. 


\section{REFERENCES}

Beasiswa, F. P. (2012, April -). Profil Kemampuan Dasar Guru. p. 1.

Kartadinata, S. (2008). Kompilasi Konseling Lintas Budaya. In S. Kartadinata, Konseling Lintas Budaya (p. 125). Bandung: Pascasarjana UPI.

Kebudayaan, D. P. (2005). Undang Undang No. 14 Tahun 2005 Tentang Guru dan Dosen. Jakarta: Departemen Pendidikan dan Kebudayaan.

Kusmiharto, H. (2007, September 09). http://file.upi.edu/Direktori/FIP/JUR._PEND._LUAR_SEKOLAH. Retrieved Januari 23, 2019, from http://file.upi.edu/Direktori/FIP/JUR._PEND._LUAR_SEKOLAH: http://www.upi.edu

Natawijaya, R. (1984). Pendidikan (Studi dan Pengajaran). Jakarta: Depdikbud.

Riyanto, T. (2002). Pembelajaran sebagai suatu Bimbingan Pribadi. Jakarta: Grasindo.

Surya, M. (2004). Psikologi Pembelajaran dan Pengajaran. Bandung: Pustaka Bani Quraisy.

Sutirna. (2004). Model Pembelajaran Matematika Bernuansa Bimbingan di SLTP. Bandung: Pascasarjana UPI.

Sutirna. (2017). Persepsi Guru PAI SMP/MTs Se Kabupaten Karawang terhadap Layanan Bimbingan dan Konseling. Wahana Karya Ilmiah Pendidikan, 1-13. 